\title{
ŽIDOVSKÝ ŽALM 19 V JEHO PRVEJ STREDOEURÓPSKEJ PODOBE
}

\author{
MARTIN PUKANEC
}

Pukanec, Martin: Jewish Psalm 19 in Its First Central European Form, 2019, Vol. 1, Issue 2, pp. 4 - 10. DOI: 10.17846/CEV.2019.01.2.4-10.

ABSTRACT: The paper offers the Old Church Slavonic (Glagolitic) translation of the Jewish Psalm 19 as well as compares Old Church Slavonic "Ne sǫtъ rěči ni slovesa ichъže ne slyšętъ sę glasi ichъ" with Old Greek

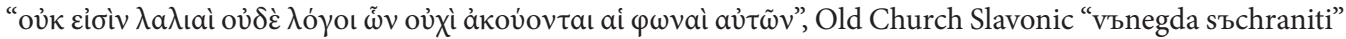

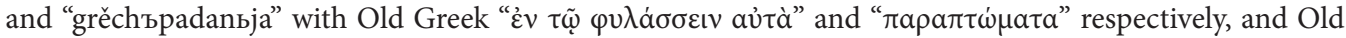

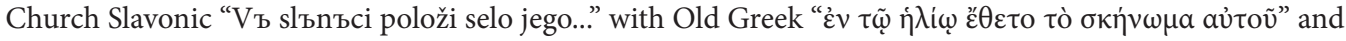

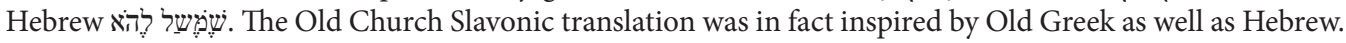

KEYWORDS: Psalms. Old Church Slavonic. Old Greek. Hebrew.

Stredoeurópske pohlady sa dnes u nás často upierajú na región krajín Vyšehradskej štvorky ako na najužšie vymedzenie strednej Európy. V nadpise tohto príspevku i v príspevku samotnom sa výraz stredoeurópsky používa s týmto významom, hoci do strednej Európy musí bezpochyby patrit ešte prinajmenšom územie Rakúska s niektorými jeho bývalými habsburskými súčastami a s velkou mierou konsenzu oblasti Nemecka a Švajčiarska s Lichtenštajnskom. Stredná Európa je pojem trochu vágny, ovela menej vágny je však význam židovstva v tomto areáli už od najstarších dejín dnešnej Európy, ktorá sa zrodila v myšlienkach karolínskej renesancie, vymedzujúcej Európu v opozícii voči islamu a východnému krestanstvu, čo nám nie náhodou trochu pripomína súčasný spôsob uvažovania.

Už niekde na priesečníku karolínskej a východorímskej tradície vznikla v rámci toho, čo sme raz nazvali mojmírovskou renesanciou (Pukanec-Schurmann-Divéky 2016, 27), definovanou hlaholikou ako úplne iným, originálnym typom písma (pozri viac napr. Kralčák 2014), prvá stredoeurópska podoba židovského žalmu 19. Tento sme si spomedzi židovských žalmov, oblúbených v krestanskej tradícii až tak, že sa považujú za hlas Cirkvi prihovárajúcej sa Kristovi (pozri Sväté písmo 1998, 993), vybrali pre potreby tejto štúdie preto, lebo hoci má len štrnást veršov, patrí dodnes medzi najinšpirujúcejšie pre umelcov (čast’ z neho spievajú napríklad Boney M. v piesni Rivers of Babylon), ale najmä preto, že už v rámci tohto žalmu nevel'kého rozsahu vidíme všetko to, čo je pre hlaholské žalmy typické: vztah k gréckej predlohe, hebrejskej pôvodine, ako i istú originalitu. Hoci na komplexné posúdenie hlaholských žalmov v článku nie je dostatok miesta, aj na malom priestore tohto jediného žalmu sa pokúsime poukázat na celkovú povahu a pôvod žalmov v ich najstaršej stredoeurópskej, moravsko-staroslovienskej podobe.

Analyzovaný židovský žalm 19 ako starosloviensky preklad žalmu XVIII z gréckej Septuaginty (počítanie sa rozlišuje odlišným spájaním a rozpájaním žalmov v jednotlivých kultúrach) sa nedochoval vo svojom najstaršom stredoeurópskom znení $\mathrm{z}$ 9. storočia, ale máme ho pomerne dobre doložený v hlaholskom Sinajskom žaltári z 11. storočia. V našom článku sa ho najprv pokúsime ako-tak verne odpísat z faksimile Sinajského žaltára (Psalterium Sinaiticum 1971, 44 - 46), pričom pod odpisom bude prepis do latinky aj s niektorými zásadnejšími poznámkami či korekciami

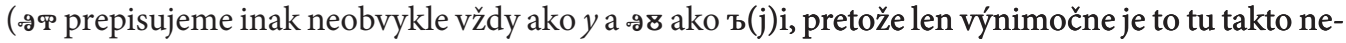
správne) a na ukážku a lepšie pochopenie slovenský preklad z Novej Vulgáty (porov. Sväté písmo 1998,1022 - 1023). Následne žalm stručne porovnáme s predlohami a rozoberieme ho $\mathrm{z}$ hladiska pôvodu. 


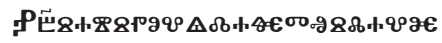

$\mathrm{N}[\mathrm{e}] \mathrm{b}[\mathrm{e}] \mathrm{sa}$ ispovědajǫtъ slavo

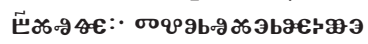

$\mathrm{B}[\mathrm{o}]$ žъjǫ, tvorъ že roqku je-

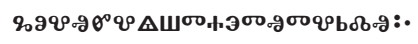

go vъzvěštajetъ tvrdъ [miesto tvrødb].

Ž 19,2 Nebesia rozprávajú o sláve Boha a obloha hlása dielo jeho rúk.

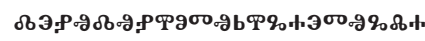

Denъ dъni otъrigajetъ gla-

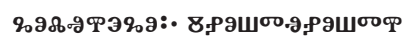

goly jego [miesto glagolø], i noštı nošti

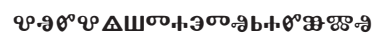

vbzvěštajetъ razumъ.

Ž 19,3 Deň dňu o tom podáva správu a noc noci to dáva na známost.

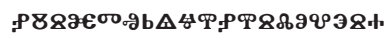

$\mathrm{Ni}[$ miesto $\mathrm{Ne}]$ sǫtъ rěči ni slovesa

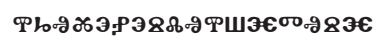

ichъže ne slyšętъ sę

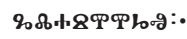

glasi ichъ.

Ž 19,4 Nie sú to slová, nie je to reč, ktorá by sa nedala počut.

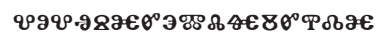

Vo vbsQ zemljo izidQ

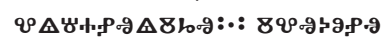

věštanъja ichъ, i vъ konь-

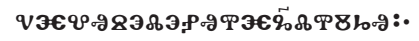

cę vъselenyję g[lago]li ichъ.

Ž 19,5 Po celej zemi rozlieha sa ich hlas a ich slová až po končiny sveta.

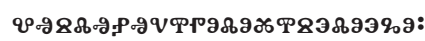

Vъ slъnъci položi selo jego,

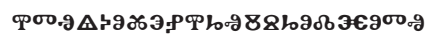

i tь jako ženichъ ischodę otъ

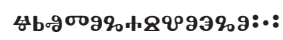

črßtoga svojego,

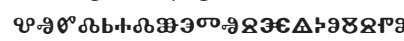

vъzdradujetъ sę jako i spo-

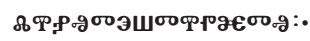

linъ tešti pǫtъ.

Ž 19,6 Tam hore vybudoval stan pre slnko a ono z neho vychádza sta ženích zo svojej komnaty a raduje sa ako bežec pred vel'kými pretekmi. 
Q\%ог

Otъ

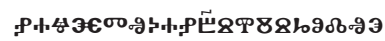

načętъka $n[e] b[e] s i$ ischodъ je-

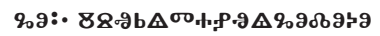

go, i sъrětanьjago [miesto srětenije jego] do ko-

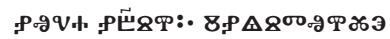

nъca $\mathrm{n}[\mathrm{e}] \mathrm{b}[\mathrm{e}] \mathrm{si}$, i něstъ iže

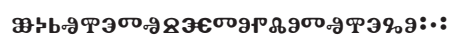

ukryjetъ sę toploty jego.

Ž 19,7 Na jednom kraji neba sa vynára a uberá sa $k$ druhému; pred jeho žiarou sa nič ukryt’ nemôže.

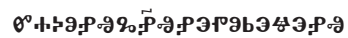

Zakonъ G[ospodь]nъ ne porečenъ

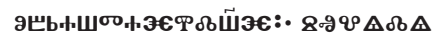

obraštajęji [miesto obraštaję] d[u]šę; sъvědě-

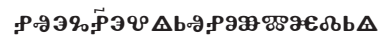

nъje G[ospodь]ne věrbno umǫdrě-

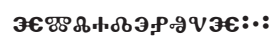

ję mladenъcę.

Ž 19,8 Zákon Pánov je dokonalý, osviežuje dušu. Svedectvo Pánovo je hodnoverné, dáva múdrost' maličkým.

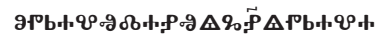

Opravъdanъja G[ospodь]ně prava

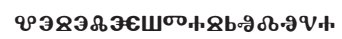

veselęšta srъdьca

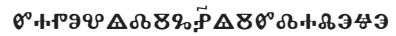

zapovědi [miesto zapověd $b$ ] G[ospodb]ně iz daleče

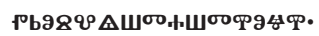

prosvěštašti [miesto prosvěštajošti] oči.

Ž 19,9 Rozhodnutia Pánove sú správne, potešujú srdce. Prikázania Pánove sú jasné, osvecujú oči.

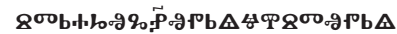

Strachъ G[ospodь $]$ nъ prěčistъ prě-

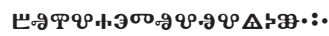

byvajetъ [miesto prěbyvaje] vb věku [miesto vo věkr věku];

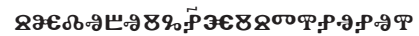

sǫdъbъi G[ospodь]nę istinıny

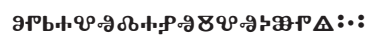

opravъdanъji vъ kupě.

Ž 19,10 Bázeň pred Pánom je úprimná, trvá naveky. Výroky Pánove sú pravdivé a všetky spravodlivé.

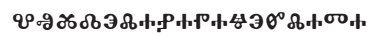

Vъždelana pače zlata 


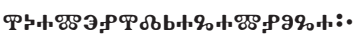

i kameni [miesto kamene] draga mnoga,

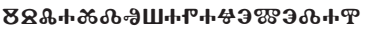

i slaždъša pače meda i

8.900н:•:

şta.

Ž 19,11 Vzácnejšie sú než zlato, než velký drahokam, sladšie sú než med, než medové kvapky z plástu.

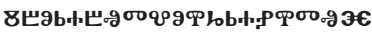

Ibo rabъ tvoi chranitъ ję

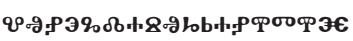

vъnegda sъchraniti ję

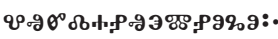

vъzdanъje mnogo.

Ž 19,12 Tvoj služobník sa v nich vzdeláva; ved'kto ich zachováva, dostane hojnú odmenu.

qobs

Grě-

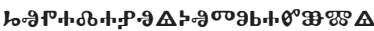

chъpadanьja kъto razumě-

э.0⿰丿:

jetъ;

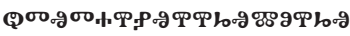

otъ tainyjichъ mojichъ

9щчв

očisti mę.

Ž 19,13 Kto však vie o všetkých svojich poblúdeniach? Očist'ma od chýb, ktorési neuvedomujem,

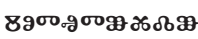

I oţ tuždu-

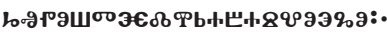

chъ [miesto tuždijichr] poštędi raba svojego;

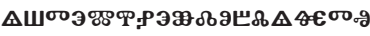

jašte mi ne udoblějǫtъ

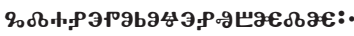

gda [miesto təgda] neporočenъ bǫdǫ,

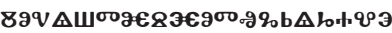

i ocěštǫ sę otъ grěcha ve-

s४⿻;:::

lika.

Ž 19,14 a svojho služobníka zachráň od pýchy, aby ma neovládala. Tak budem bez škvrny a čistý od velkého hriechu.

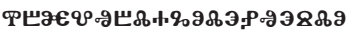

I bo [miesto bodotr] vъ blagolenъje [miesto blagovolenzje] slo-

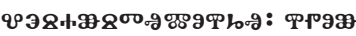

vesa ustъ mojichъ, i pou- 


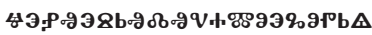

čenъje srъdъca mojego prě-

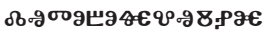

$\mathrm{d} ъ$ tobojǫ vъing̨

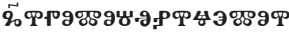

G[ospod]i pomoštbniče moi

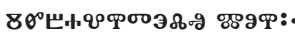

izbavitelъ [miesto $i$ izbavitelju] moi.

Ž 19,15 Nech sa ti páčia slová mojich úst i rozjímanie môjho srdca pred tvojou tvárou. Pane, ty si moja pomoc a môj vykupitel.

Ako už v samotnom prepise s poznámkami vidíme, v Sinajskom žaltári sa vyskytuje množstvo chýb, ktoré treba opravovat podla iných rukopisov žaltára (porov. Vaillant 1992, 36 - 38), príp. širších znalostí staroslovienčiny. Ked’ porovnávame najstarší dochovaný slovanský preklad žalmov s gréckou Septuagintou (pozri Anonymous 2013, 1969 - 1970, kde ale, žial, chýbajú niektoré grécke diakritické znamienka alebo sú nepresné, takže ich doplníme) a s hebrejskou pôvodinou (The Hebrew-English Interlinear ESV Old Testament 2014, 1248 - 1249), objavíme v staroslovienskom znení zopár zaujímavých skutočností, na ktoré treba bližšie upriamit pozornost'.

Takto v prvom rade vo vete označenej podla nášho prekladu z Novej Vulgáty Ž 19,4: Ne sotz rěči ni slovesa ichъže ne slyšętr sę glasi ichr, vidíme pleonazmus, aký je aj v gréčtine: oủк eỉoiv

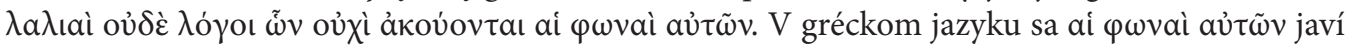
nadbytočné rovnako ako slovanské se glasi ichr. V prípade slovanskej podoby tu ide teda určite o kalk z gréčtiny. Daný jav ostatne v hebrejskej pôvodine nevidíme, čo takýto výklad len potvrdzuje. To, že starosloviensky text vychádza z gréckej Septuaginty, je, samozrejme, prirodzené, kedže jeho prekladatel'mi boli, ako je všeobecne známe, solúnski Gréci.

Uvedené tvrdenie však vyzerá čiastočne inak vo svetle vety Ž 19,12, ktorej druhá čast’ દ̇v

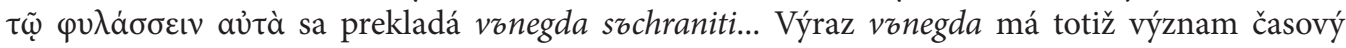
(pozri ESJS 5 1995, 279), ktorý grécke znenie nemá. Poukazuje to na to, že pri prevádzaní žalmu do staroslovienčiny nemožno vylučovat určitú tvorivú invenciu prekladatela. Toto potvrdzuje aj vel’mi zvláštne zložené pomenovanie grěchrpadanıja „upadnutie (upadanie) do hriechu“ (pozri

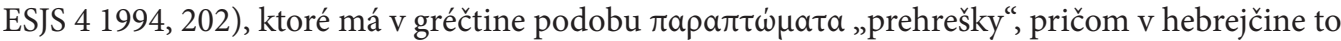
nie je velmi odlišné od gréčtiny, takže prekladatelovi, ak by sa iba pevne pridŕžal gréckej predlohy, by bol býval stačil napísat jednoducho príslušný tvar samotného výrazu grěch $\mathrm{b}$.

Najvýznamnejšou otázkou celého žalmu však je, prečo na začiatku Ž 19,6 čítame $V$ z slønøci položi selo jego... V gréckej Septuaginte, ktorú musíme aj na základe už spomenutého považo-

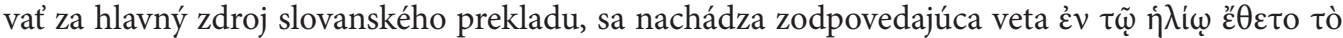

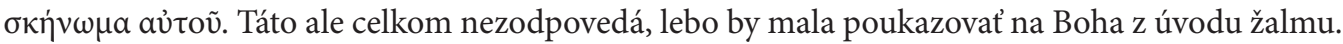
Inak to ostatne nie je ani v latinskej Vulgáte. V staroslovienčine by sme preto očakávali znenie prekladu $V$ z slanzci položi selo svoje... Z uvedeného staroslovienskeho textu však vyplýva, že ono selo „príbytok“ malo byt pre slnce. Velmi dôležité je, že presne takto to je i v hebrejskej pôvodine, len tam nejde o akýsi príbytok či sídlo, lež konkrétne o stan לֶּ [o’hel], čo má byt doslova „pre

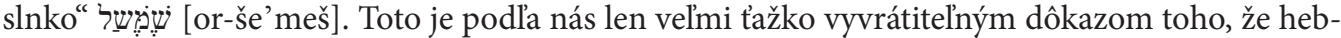
rejské znenie ovplyvnilo prvú stredoeurópsku podobu židovského žalmu 19 tiež priamo, nielen prostredníctvom gréčtiny.

Aj na základe spomínaného množstva chýb pri prepise vidíme, že rukopis takzvaného Sinajského žaltára bez akýchkolvek pochybností nie je protografom, čiže pôvodným, prvým písomným záznamom textu. Na moravsko-starosloviensky, resp. česko-slovenský pôvod či aspoň výskyt pamiatky poukazuje napríklad už spomínané pomenovanie šchraniti, v tej istej vete žalmu 
je aj chranitz. A to $\mathrm{z}$ toho dôvodu, že sloveso $(s z)$ chraniti $<{ }^{\star}(s \tilde{s})$ chorniti má v južnoslovanských jazykoch význam „kŕmit“, kým význam „chránit“" ktorý nesie daný výraz v našom žalme, sa vyskytuje len v západnej a východnej slovančine (pozri ESJS 4 1994, 226 - 227), pričom v polšstine a východnej slovančine by formálne vypadalo inak, kedže v ňom neprebehla príslušná metatéza likvíd. Menej istým západoslovanským prvkom môže byt ešte i nominatív izbavitelı vo funkcii vokatívu. Na južnú slovančinu však dostatočne okrem iného poukazuje prítomnost’ epentetického l'(zemljo), predložka a predpona iz, predpona výrazov razumz/razumějetz, no najmä podoby slov ako noštb < ${ }^{\star}$ nokt-, tešti < ${ }^{\star}$ tekt-, pomoštb- < ${ }^{\star}$ pomogt- či $t u z ̌ d-<{ }^{\star} t u d-$, ktoré svojimi palatalizáciami nemôžu byt iné ako bulharské.

Hoci text samotného Sinajského žaltára sa na rozdiel od pôvodného textu žalmov nepoužíval v nami úzko vymedzenom priestore strednej Európy, teda v moravskej či moravsko-panónskej staroslovienčine, ale až neskôr v nevelmi odlišnej klasickej, bulharsko-macedónskej staroslovienčine, na znení analyzovaného žalmu vidíme, že má i česko-slovenské črty, ktoré sa nedajú spochybnit' (sémantika slovesa (sz)chraniti). Ako presne vyzeral židovský žalm $19 \mathrm{v}$ jeho prvej stredoeurópskej podobe teda úplne nevieme, vieme však z jeho podoby v 11. storočí upozornit’ aspoň na jednu zásadnú skutočnost', a to že jeho predlohou nemusela byt' len grécka Septuaginta, ale aj hebrejský text žalmu. Židovskú kultúru do strednej Európy priniesli najskôr solúnski Gréci; v Živote Konštantína sa explicitne dozvedáme, že sa tento naučil židovskú reč i písmo (pozri MMFH II 1967, 77). Židovská kultúra takto stála nielen prostredníctvom krestanstva, lež i bezprostredne pri samotnom zrode kultúry dnešných stredoeurópskych krajín. Rozbor dalších žalmov Sinajského žaltára by túto tézu potvrdil ešte výraznejšie.

\section{SUMMARY}

The paper offered the Old Church Slavonic (Glagolitic) translation of the Jewish Psalm 19 as well as

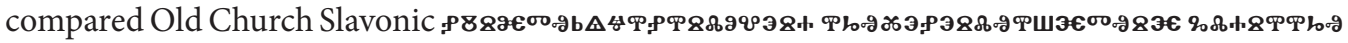

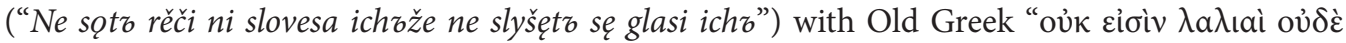

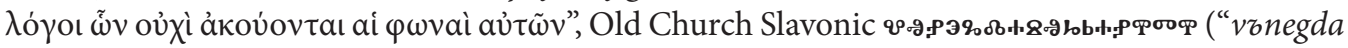

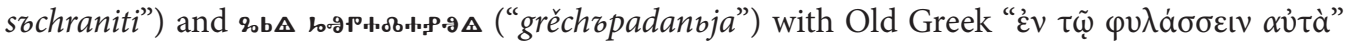

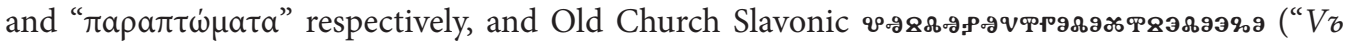

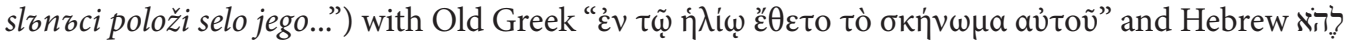
שֶׁp. The analyzed Glagolitic manuscript (Psalterium Sinaiticum, the 11th Century Glagolitic manuscript from St. Catherine's Monastery, Mount Sinai) is Old Bulgarian (epenthetic l', preposition and prefix $i z$, prefix in razumø/razumějetz, palatalized noštb $<{ }^{\star}$ nokt-, tešt $i<{ }^{\star}$ tekt-, pomoštb$<{ }^{*}$ pomogt- and tužd- < ${ }^{\star}$ tud-) with Old Moravian features (chraniti 'protect' < ${ }^{*}$ chorniti, etc.). However, the Old Church Slavonic translation was originally Old Moravian (Central European) and in fact inspired by Old Greek as well as Hebrew.

\section{LITERATÚRA}

Anonymous, 2013. Interlinear Greek English Septuagint Old Testament (LXX). Delhi: Isha Books. ESJS 4, 1994 - Etymologický slovník jazyka staroslověnského 4. gospodo - istnoti. Doplňky k bibliografickému aparátu I. Hl. red. E. Havlová. Praha: Academia, nakladatelství Akademie věd České republiky, 193 - 252.

ESJS 5, 1995 - Etymologický slovník jazyka staroslověnského 5. Istopiti sę - klęti. Hl. red. E. Havlová. Praha: Academia, nakladatelství Akademie věd České republiky, 253 - 316.

Kralčák, Lubomír, 2014. Pôvod hlaholiky a Konštantínov kód. Martin: Matica slovenská. 
MMFH II, 1967 - Magnae Moraviae fontes historici II. Textus biographici, hagiographici, liturgici. Brno: Universita J. E. Purkyně.

Psalterium Sinaiticum, 1971. An 11th century Glagolitic manuscript from St. Catherine's Monastery, Mt. Sinai. Ed. M. Altbauer. Skopje: Macedonian Academy of Sciences and Arts 1971.

Pukanec-Schurmann-Divéky, Martin, 2016. Histoire du royal Pays slovaque. De l'indépendance aux États-Désunis d’Autriche-Hongrie. Saint-Denis: Edilivre.

Sväté písmo, 1998. Trnava: Spolok svätého Vojtecha.

The Hebrew-English Interlinear ESV Old Testament, 2013. Ed. T. Blair. Wheaton: Crossway 2013.

Vaillant, André, 1992. Manuel du vieux slave II. Textes et glossaire. Paris: Institut d'Études slaves.

\section{KONTAKT}

doc. Mgr. Martin Pukanec, PhD.

Katedra slovenského jazyka a literatúry

Filozofická fakulta UKF v Nitre

Štefánikova 67

94974 Nitra

Slovenská republika

mdpukanec@ukf.sk 